\title{
Distribution and Diversity of Geminiviruses in Trinidad and Tobago
}

\author{
Pathmanathan Umaharan, Malla Padidam, Ralph H. Phelps, Roger N. Beachy, and Claude M. Fauquet
}

\begin{abstract}
First and third authors: Department of Plant Science, The University of the West Indies, St. Augustine, Republic of Trinidad and Tobago; and second, fourth, and fifth authors: International Laboratory for Tropical Agricultural Biotechnology (ILTAB/ORSTOM-TSRI), Division of Plant Biology-BCC206, The Scripps Research Institute, La Jolla, CA 92037. Accepted for publication 19 August 1998.
\end{abstract}

\begin{abstract}
Umaharan, P., Padidam, M., Phelps, R. H, Beachy, R. N., and Fauquet, C. M. 1998. Distribution and diversity of geminiviruses in Trinidad and Tobago. Phytopathology 88:1262-1268.

Seven crop and eight weed species from 12 agricultural locations in Trinidad and Tobago were assayed for the presence of whitefly-transmitted geminiviruses (WTGs) by using dot blot hybridization and polymerase chain reaction (PCR) amplification of the N-terminal coat protein sequence with degenerate primers. The amplified fragments were cloned and analyzed by restriction enzyme digestion to determine fragment length polymorphism among the cloned fragments. Representative clones were then sequenced and subjected to phylogenetic analysis to determine the sequence similarity to known WTGs. WTGs were found in every location sampled and in 10 of the 15 species investigated: Lycopersicon esculentum

(tomato), Capsicum annuum (pepper), Capsicum frutescens (sweet pepper), Abelmoschus esculentus (okra), Phaseolus vulgaris (beans), Alternanthera tenella, Desmodium frutescens, Euphorbia heterophylla, Malva alceifolia, and Sida acuta. The geminiviruses infecting these plants were closely related to potato yellow mosaic virus from Venezuela (PYMV-VE) and tomato leaf curl virus from Panama (ToLCV-PA). However, in pepper, sweet pepper, okra, Alternanthera tenella, Euphorbia heterophylla, Desmodium frutescens, and in one sample of tomato, a PYMV-VE-related virus was found in mixed infections with a virus related to pepper huasteco virus. Full-length infectious DNA-A and DNA-B of a tomato-infecting geminivirus from Trinidad and Tobago were cloned and sequenced. DNA-A appears to be a recombinant derived from PYMV-VE or ToLCV-PA, and Sida golden mosaic from Honduras. The implications of these findings in the control of WTGs are discussed.
\end{abstract}

Geminiviruses (family Geminiviridae) constitute an important group of plant pathogens and are characterized by their twinned isometric particles and circular, single-stranded DNA genomes (13, 16). Geminiviruses are subdivided into three genera on the basis of host range, insect vector, and genome organization $(18,20)$. The genus Begomovirus (subgroup III) consists of viruses that are transmitted by whiteflies to dicotyledonous plants. The whitefly-transmitted geminiviruses (WTGs) that are endemic to the Americas have bipartite genomes designated as DNA-A and DNA-B (each $\approx 2,600$ nucleotides). Genes on DNA-A encode functions that are required for viral replication and encapsidation, while genes on DNA-B are required for viral movement in plants $(6,16,31)$.

With the emergence of the sweetpotato whitefly (Bemisia tabaci, biotype-A) and silver leaf whitefly (B. tabaci, biotype-B, or $B$. argentifolii) as important pests in the Caribbean basin and Central America in recent times, WTGs have become an important constraint to vegetable production in the region. Many WTG-associated diseases in the Caribbean are caused by a complex of yet-to-becharacterized geminiviruses (2). One such disease characterized by symptoms of severe leaf mottling, leaf curling, and leaf size reduction was first observed in epiphytotic proportions in tomato (Lycopersicon esculentum) fields in the north of Trinidad during 1989. Since then, the disease has spread throughout the country and poses a severe threat to the tomato industry. Similar virus-like infections were also observed in other agricultural crops and weed species in the vicinity of tomato fields.

The objective of this study was to identify whether WTGs were involved in these disorders and, if so, to determine the identity,

Corresponding author: C. M. Fauquet; E-mail address: iltab@scripps.edu

GenBank accession numbers for the nucleotide sequences are AF039031 and AF039032.

Publication no. P-1998-1012-01R

(C) 1998 The American Phytopathological Society diversity, and host range of the causal agent. We used degenerate primers to amplify and sequence the $\mathrm{N}$-terminal coat protein $(\mathrm{CP})$ region of the putative geminiviruses to study the diversity of WTGs in the agricultural environs in Trinidad and Tobago. We also cloned and sequenced a full-length infectious clone of the geminivirus infecting tomato.

\section{MATERIALS AND METHODS}

Collection of plant samples. Samples from 12 locations representing the major tomato-growing areas in Trinidad and Tobago were collected during August 1995. Tomato leaf samples (from a single plant per location) showing disease symptoms were collected from all the locations where a tomato crop was present at the time of sampling. In addition, leaf samples from other crop and weed species that showed virus-like symptoms in the areas around these locations were also collected (Table 1). The weeds were found bordering the crop fields or as an underbrush within them. The other crop species sampled included pepper (Capsicum annuum), sweet pepper (Capsicum frutescens), okra (Abelmoschus esculentus), pumpkin (Cucurbita maxima), bitter gourd (Mormordica charantia), and bean (Phaseolus vulgaris). The weed species sampled included Euphorbia heterophylla, Acalypha arvensis, Alternanthera tenella, Malva alceifolia, Merramia aegyptia, Phenax sonneratii, Desmodium frutescens, and Sida acuta. In one location (Pasea), tomato leaf samples were collected in two subsequent seasons.

Dot blot, polymerase chain reaction (PCR) cloning, and sequencing. Plant DNA was extracted from 1 to $2 \mathrm{~g}$ of frozen tissue from each sample according to the procedure described by Dellaporta et al. (7), and $2 \mu \mathrm{g}$ of DNA was subjected to dot blot hybridization (28) using a ${ }^{32} \mathrm{P}$-labeled probe prepared from fulllength DNA-A of tomato mottle virus (ToMoV) $(1,24)$. Hybridization and washing were carried out at moderate stringency conditions $\left(55^{\circ} \mathrm{C}, 1 \times \mathrm{SSC}[0.15 \mathrm{M} \mathrm{NaCl}\right.$ plus $0.015 \mathrm{M}$ sodium citrate]) following standard protocols (29). 
Two degenerate primers (MP16 and MP82) were designed to amplify the sequence from the invariable nonanucleotide (TAATATTAC) in the conserved stem-loop region to the sequence encoding eight invariable amino acids (CEGPCKVQ, around amino acids 60 to 70 ) present in the N-terminal region of the $\mathrm{CP}$ of WTGs. The oligonucleotide sequences of these primers were MP16, 5'-CCTCTAGATAATATTACCKRWKGRCC-3'; and MP82, 5'-CGGAATTCYTGNACYTTRCANGGNCCYTCRCA-3' (recognition sites for restriction enzymes $X b a \mathrm{I}$ and EcoRI are underlined). The primers were expected to amplify a $\approx 400$ - to 500-bp fragment of DNA-A of WTGs, depending on the virus. The PCR reactions $(100 \mu \mathrm{l})$ contained 0.5 to $1.0 \mu \mathrm{g}$ of plant DNA; $20 \mathrm{mM}$ Tris- $\mathrm{HCl}, \mathrm{pH} 8.4 ; 50 \mathrm{mM} \mathrm{KCl} ; 2.5 \mathrm{mM} \mathrm{MgCl}_{2} ; 0.2 \mathrm{mM} \mathrm{dNTP}$; 2.5 units of Taq polymerase (Gibco BRL, Bethesda, MD); and 100 pmoles of each primer. Amplification was achieved by 30 cycles of 1 min of denaturation at $94^{\circ} \mathrm{C}, 1 \mathrm{~min}$ of annealing at $55^{\circ} \mathrm{C}$, and $2 \mathrm{~min}$ of extension at $72^{\circ} \mathrm{C}$. The amplification products were separated on an agarose gel, and DNA fragments in the $\approx 300$ to 600-bp region were eluted and cloned into pBluescript $\mathrm{SK}^{-}$. Miniprep plasmid DNA isolated from 15 colonies for each amplification product cloned was analyzed for insert length after digesting with EcoRI and $\mathrm{XbaI}$. Two to six clones from each amplified product (63 in all) were sequenced with the M13 forward primer (which binds to the $\mathrm{SK}^{-}$vector on the $\mathrm{CP}$ sequence side of the insert) using the Applied Biosystem 370A DNA sequencer (Applied Biosystems, Inc., Foster City, CA).

Cloning of full-length infectious viral DNA. Total nucleic acids isolated from the infected tomato plant collected at Pasea were separated on a $1 \%$ agarose gel, blotted onto a nylon membrane (29), and probed with radioactively labeled DNA-A and DNA-B of ToMoV to identify the position of double-stranded viral DNA. Covalently closed circular viral DNA was gel-isolated and digested with several restriction enzymes to identify unique sites. Putative full-length DNA-A (linearized with Bam HI) and DNA-B (linearized with ApaI) were isolated from an agarose gel and cloned into pBluescript $\mathrm{SK}^{-}$. Partial tandem dimers of DNA-A (clone pUA1) and DNA-B (clone pUB1) were prepared as previously described for squash leaf curl virus (17) and inoculated onto Nicotiana benthamiana and tomato plants by particle bombardment with a helium-driven particle accelerator from Bio-Rad (Bio-Rad Laboratories, Hercules, CA) (19) and by agroinoculation (4), respectively. For agroinoculation of plants, the partial dimers were inserted into the binary vector pMON977 and introduced into Agrobacterium tumefaciens strain $\mathrm{ABI}$, and plants were inoculated as described elsewhere (4). The DNA sequence of both strands of the pUA1 and pUB1 clones was determined following subcloning.

Sequence analysis. The nucleotide sequences coding for the first 61 amino acids of the CP of 63 PCR clones and the full-length clone were compared with known sequences of WTGs using the MegAlign program available with DNASTAR (version 1.02; DNASTAR Inc., Madison, WI). The cluster algorithm of MegAlign makes no a priori assumptions on relatedness and preserves gaps that occur in earlier alignments through later stages. Percent similarity between sequences $i$ and $j$ is given as $100 \times$ sum of matches/ (length - gap residues $i$ - gap residues $j$ ). Different gap and gap length penalties were used initially to see the effect on alignment, but no significant differences were observed. Phylogenetic analysis was done using the unweighted pair group method with arithmetic means (UPGMA) distance matrix and neighborhood-joining method available with the MegAlign program. A random sequence of equal length and nucleotide composition was included in all alignments.

TABLE 1. Dot blot hybridization and polymerase chain reaction (PCR) detection of whitefly-transmitted geminiviruses in 15 plant species collected from 12 locations in Trinidad and Tobago in 1995

\begin{tabular}{|c|c|c|c|c|c|}
\hline \multirow[b]{2}{*}{ Plant species } & \multirow[b]{2}{*}{ Location } & \multirow[b]{2}{*}{ Isolate } & \multirow[b]{2}{*}{ Dot blot } & \multicolumn{2}{|c|}{ PCR clones ${ }^{\mathrm{a}}$} \\
\hline & & & & $\approx 425 \mathrm{bp}$ & $\approx 475 \mathrm{bp}$ \\
\hline \multirow[t]{9}{*}{ Lycopersicon esculentum (tomato) } & Pasea (January) & Le15 & + & 15 & None \\
\hline & Pasea (April) & Le4 & + & 15 & None \\
\hline & Santa Cruz & Le9 & + & 13 & None \\
\hline & Santa Cruz & Le9A & + & 15 & None \\
\hline & Aranguez & Le20 & + & 12 & None \\
\hline & Trincity & Le23 & + & 13 & 2 \\
\hline & Freeport & Le25 & + & 11 & None \\
\hline & Puzzle Island & Le30 & + & 15 & None \\
\hline & Siparia & Le32 & + & 15 & None \\
\hline \multirow[t]{6}{*}{ Capsicum аппиит (pepper) } & Chaguaramas & $\mathrm{Ca} 7$ & + & 13 & 1 \\
\hline & Paramin & $\mathrm{Ca} 8$ & + & 11 & 1 \\
\hline & Macoya & $\mathrm{Ca} 17$ & + & 11 & None \\
\hline & Macoya & Ca19 & + & 12 & 5 \\
\hline & Puzzle Island & $\mathrm{Ca} 28$ & + & 13 & 2 \\
\hline & Aranguez & $\mathrm{Ca} 31$ & + & 14 & 1 \\
\hline \multirow[t]{3}{*}{ Capsicum frutescens (sweet pepper) } & Valsayn & Cf14 & + & 11 & 1 \\
\hline & Valsayn & Cf15 & + & 13 & None \\
\hline & Freeport & Cf26 & + & 10 & None \\
\hline Phaseolus vulgaris (bean) & Santa Cruz & Pv12 & + & 12 & None \\
\hline Abelmoschus esculentus (okra) & Macoya & Ae18 & + & 14 & 2 \\
\hline Cucurbita maxima (pumpkin) & Puzzle Island & $\mathrm{Cm} 32$ & - & None & None \\
\hline Mormordica charantia (bitter gourd) & Aranguez & Mc33 & - & None & None \\
\hline Acalypha arvensis & Santa Cruz & Aa10 & - & None & None \\
\hline Alternanthera tenella & Chaguaramas & At5 & + & 10 & 6 \\
\hline Desmodium frutescens & Santa Cruz & Df9 & + & 15 & none \\
\hline \multirow[t]{2}{*}{ Euphorbia heterophylla } & Chaguaramas & Eh2 & + & 15 & None \\
\hline & Valsayn & Eh16 & + & 13 & 1 \\
\hline \multirow[t]{2}{*}{ Malva alceifolia } & Chaguaramas & Ma6 & + & 10 & 4 \\
\hline & Barataria & Ma13 & - & None & None \\
\hline Merramia aegyptia & Trincity & $\mathrm{Me} 21$ & - & None & None \\
\hline Phenax sonneratii & Santa Cruz & Ps11 & - & None & None \\
\hline Sida acuta & Chaguamas & $\mathrm{Sa} 3$ & + & $11^{\mathrm{b}}$ & 4 \\
\hline
\end{tabular}

a Number of PCR clones showing the corresponding insert size.

b Seven clones had 400-bp inserts and four clones had 450-bp inserts. 


\section{RESULTS AND DISCUSSION}

Young leaves were collected from symptomatic tomato, pepper, bean, okra, pumpkin, bitter gourd, and eight weed species growing in 12 major tomato-cultivating regions in Trinidad and Tobago during 1995. The typical symptoms of collected leaf samples included yellow mottling, crinkling, curling, and severe stunting. These samples were examined for geminivirus DNA by using dot blot hybridization methods. Table 1 summarizes the results of dot blot hybridization. Geminivirus DNA was detected in tomato, pepper, sweet pepper, okra, and beans, but not in bitter gourd or pumpkin. Among the weed species investigated, Alternanthera tenella, Desmodium frutescens, Euphorbia heterophylla, Malva alceifolia, and Sida acuta were found to be infected with geminiviruses, while Acalypha arvensis, Merramia aegyptia, Phenax sonneratii, and one sample of Malva alceifolia were negative in dot blot tests. None of the locations sampled were free of WTGs, and every sample of tomato and pepper collected throughout the country was positive for the presence of geminivirus, indicating the widespread nature of these viruses.

To characterize these geminiviruses, we amplified the $5^{\prime}$-CP sequences by PCR using the degenerate primers MP16 and MP82. Earlier studies have shown that the N-terminal region (60 to 70 amino acids) of the $\mathrm{CP}$ is more variable than the rest of the $\mathrm{CP}$ sequence and representative of the sequence of the complete genome $(14,15)$. The amplified fragments in the 300 - to 600-bp region were sub-

TABLE 2. Nucleotide sequence identity between the N-terminal coat protein regions of Trinidad and Tobago geminivirus isolates that yielded $\approx 425$ - and $\approx 475$-bp polymerase chain reaction fragments and other whitefly-transmitted geminiviruses

\begin{tabular}{lcc}
\hline & \multicolumn{2}{c}{ Nucleotide sequence identity (\%) } \\
\cline { 2 - 3 } Geminivirus $^{\text {a }}$ & $\approx 425$-bp fragment & $\approx 475$-bp fragment \\
\hline AbMV (West Indies) & $79-84$ & $51-59$ \\
BDMV (Colombia) & $81-84$ & $55-60$ \\
BGMV-BR (Brazil) & $71-75$ & $56-59$ \\
BGMV-PR (Puerto Rico) & $58-62$ & $53-56$ \\
CaLCV (Florida) & $67-76$ & $56-60$ \\
CLCrV (Arizona) & $66-71$ & $56-61$ \\
PepGMV (Mexico) & $63-72$ & $61-66$ \\
PHV (Mexico) & $60-63$ & $94-98$ \\
PYMV-VE (Venezuela) & $90-95$ & $55-63$ \\
SiGMV-CR (Costa Rica) & $65-76$ & $51-54$ \\
SiGMV-Flo (Florida) & $74-87$ & $55-62$ \\
SiGMV-HN (Honduras) & $71-85$ & $55-60$ \\
SiGMV-HN/Yv (Honduras) & $70-84$ & $52-58$ \\
SLCV (California) & $71-76$ & $57-59$ \\
TGMV-BR (Brazil) & $71-75$ & $59-61$ \\
TLCrV (Mexico) & $81-83$ & $53-59$ \\
ToLCV-PA (Panama) & $91-95$ & $55-64$ \\
ToMoV (Florida) & $83-86$ & $56-62$ \\
ToMoV-Tai (Cuba) & $68-84$ & $56-61$ \\
ToLCV-Nde (India) & $40-42$ & $39-43$ \\
\hline
\end{tabular}

a Geminivirus names and GenBank accession numbers: AbMV, Abutilon mosaic virus from West Indies (X15983, X15984); BDMV, bean dwarf mosaic virus from Columbia (M88179, M188180); BGMV-BR, bean golden mosaic virus from Brazil (M88687, M88687); BGMV-PR, BGMV from Puerto Rico (M10070, M10080); CaLCV, cabbage leaf curl virus from Florida (U65529); CLCrV, cotton leaf crumple virus from Arizona (Z. Xiong, personal communication); PepGMV, pepper golden mosaic virus from Mexico (U57457); PHV, pepper huasteco virus from Mexico (X70418, X70419); PYMV-VE, potato yellow mosaic virus from Venezuela (D00940, D00941); SiGMV-CR, Sida golden mosaic virus from Costa Rica (X99550, X99551); SiGMV-Flo, SiGMV from Florida (AF039841, AF0049336); SiGMV-HN, SiGMV from Honduras (Y11097, Y11098); SiGMV-HN/Yv, SiGMV yellow vein strain from Honduras (Y11099, Y11100); SLCV, squash leaf curl virus from California (M38182, M38183); TGMV-BR, tomato golden mosaic virus from Brazil (K020029, K02030); TLCrV, tomato leaf crumple virus from Mexico (L34747); ToLCV-PA, tomato leaf curl virus from Panama (Y15033, Y15034); ToMoV, tomato mottle virus from Florida (L14460, L14461); ToMoV-Tai, ToMoV Taino strain from Cuba (AF012300, AF012301); and ToLCV-Nde, tomato leaf curl virus from New Delhi, India (U15015, U15016). sequently cloned. A total of 15 recombinant plasmid clones obtained from each amplified sample were digested with $X b a \mathrm{I}$ and EcoRI (enzymes used for cloning) and analyzed on an agarose gel to detect fragment length polymorphisms. Recombinant plasmids obtained from amplified products of all tomato samples consistently yielded fragments $\approx 425$ bp in length, except in a sample from Trincity, which yielded fragments of $\approx 475 \mathrm{bp}$ in length at a low frequency (Table 1). Out of the nine pepper and sweet pepper samples evaluated, clones from six samples had 425- or 475-bp fragments, the former at a much higher frequency than the latter, while clones from the other three samples had only the 425-bp fragment (Table 1). Clones obtained from bean contained only 425-bp amplified fragments, while those from okra contained either 425- or 475-bp fragments; again, the latter occurred at a lower frequency than the former. In general, more than one fragment length was amplified in the weed species investigated, with the exception of the samples from Desmodium frutescens, from which a single amplified fragment of $\approx 425$ bp was recovered. Only $8 \%$ of all recombinant clones analyzed (30/365) had a 475-bp fragment.

Representative clones from each sample (two to six per sample, total 63) were then sequenced. Comparison of the CP N-terminal nucleotide sequences of these clones with those of other WTGs showed that all fragments of the $\approx 425$-bp size were more closely related to potato yellow mosaic virus from Venezuela (PYMV-VE) (5) and tomato leaf curl virus from Panama (ToLCV-PA, GenBank accession \#Y15034) than to any other WTGs from the Americas, whereas the $\approx 475$-bp size fragments were more closely related to pepper huasteco virus (PHV) from Mexico (32) (Table 2). The percent nucleotide identities between the clones of 425-bp length and PYMV-VE and ToLCV-PA varied from 90 to $95 \%$, and between the clones of 475-bp length and PHV varied from 94 to $98 \%$. The percent identity within the 425-bp group and within the 475-bp group ranged from 90 to $98 \%$ and 90 to $99 \%$, respectively, while that between the 425-bp group clones and the 475-bp group clones varied from 59 to $70 \%$, indicating that the isolates that gave 425 and 475-bp fragments belonged to two distinct viruses. In Sida acuta, the 475-bp fragment was an amplification product of a PHV-related virus, while the other fragments $(\approx 400$ and $\approx 450 \mathrm{bp})$ did not have significant sequence homology (21 to $35 \%$ ) to any other geminiviruses or to sequences in the GenBank database, and probably represent plant sequences. Phylogenetic analysis showed that isolates that gave rise to 425-bp PCR fragments clustered on a separate branch of the phylogenetic tree, but adjacent to the branch that contained PYMV-VE and ToLCV-PA; while the isolates that gave rise to 475-bp fragments were grouped together with PHV on the same branch (Fig. 1). A closer examination of sequence comparisons revealed that the variation among isolates that yielded 425-bp fragments from different plant species or locations was not greater than the variation observed among clones obtained from a single isolate. For instance, clones from tomato samples Le9 (Le9-1, Le9-4, Le9-9, and Le9A-1) and Le25 (Le25-2, Le25-6, and Le25-9) clustered together, although the two samples were from different locations. Similarly, no significant differences were present between tomato samples Le1-2 and Le2-3 that were collected in different seasons but from the same location (Pasea). On the basis of this relationship, the Trinidad and Tobago geminiviruses yielding 425-bp PCR fragments appear to be strains or isolates of PYMVVE and ToLCV-PA, and the geminiviruses yielding 475-bp fragments appear to be strains or isolates of PHV. The variation observed within PYMV-VE- and ToLCV-PA-related or PHV-related isolates may reflect the normal variation that can occur within a virus species $(14,20)$.

Mixed geminivirus infection appears to be common in Trinidad and Tobago, with eight out of the nine plant species positive for geminiviruses showing evidence of mixed infections. PHV-related isolates (i.e., geminiviruses yielding 475-bp fragments) were consistently the rarer component in mixed infections with, on average, only $8 \%$ of the clones analyzed belonging to this group. Interest- 
ingly, there was no single case in which the PHV-related isolates were observed in the absence of PYMV-VE- and ToLCV-PA-related isolates. In Mexico, PHV is considered to be one of a complex of geminiviruses involved in the rizado amarillo disease complex in pepper (11). Similarly, two geminiviruses, pepper mild tigre virus and chino del tomato virus, were implicated in the tigre disease of pepper $(2,3)$. Hence, the incidence of more than one geminivirus leading to a complex of symptoms in crop plants is not uncommon and perhaps may be the norm rather than the exception.

Our data show that PYMV-VE- and ToLCV-PA-related isolates were present in 9 of the 15 plant species tested and in every location tested. To further characterize the tomato-infecting geminivirus, a full-length infectious DNA-A and DNA-B were cloned from a tomato plant (sample Le15) as described above. Nicotiana benthamiana and tomato plants were inoculated with partial tandem repeats of DNA-A and DNA-B by particle bombardment and agroinoculation, respectively. Nicotiana benthamiana (four out of five) and tomato (7 out of 10) plants inoculated with both DNA-A and DNA-B showed severe symptoms within 3 weeks, but the plants inoculated with DNA-A alone did not develop infection even after 5 weeks postinoculation (data not shown). The typical symptoms consisted of severe leaf size reduction, leaf puckering, and mottling. Southern blot analysis of DNA isolated from systemically infected leaves using a probe prepared from cloned DNA-A showed that inoculated plants contained both single- and double-stranded viral DNA (data not shown).

Sequencing of the full-length infectious DNA-A and DNA-B clones showed that the genome organization of this tomato isolate is similar to that of other WTGs (Fig. 2). The cloned DNA-A is 2,582 nucleotides in length and encodes one virion-sense open reading frame (ORF) (AV1) and four complementary-sense ORFs (AC1 to AC4), whereas DNA-B (2,535 nucleotides) has the capacity to encode two ORFs, one virion sense (BV1) and one complementary sense (BC1). DNA-A and DNA-B have no homology except for a 165-bp sequence in the intergenic region (IR, sequence between intiation codons of $\mathrm{AC} 1$ and $\mathrm{AV} 1$ genes) that is termed the common region (CR). The $\mathrm{CR}$ contained the invariable nonanucleotide sequence (TAATATTAC) that is present in all geminiviruses isolated to date. Genetic analysis of other WTGs previously established that ORFs AV1, AC1, AC2, and AC3 encode the CP, the replication associated protein (Rep), the transcriptional activator protein (TrAP), and the replication enhancer protein (REn), respectively $(16,31)$. The BV1 and BC1 ORFs on DNA-B encode the nuclear shuttle protein (NSP) and the cell-to-cell movement protein

Fig. 1. Phylogenetic tree obtained from the alignment of the N-terminal coat protein nucleotide sequences of 39 whitefly-transmitted geminivirus (WTG) isolates from Trinidad and Tobago with those of other WTGs from the Americas. Horizontal scale below measures the distance between sequences, and vertical distances are arbitrary. Isolates from Trinidad and Tobago are designated by two letters and a number. The second number after the hyphen refers to the clone number. Other geminiviruses (GenBank accession numbers) are AbMV, Abutilon mosaic virus from West Indies (X15983, X15984); BDMV, bean dwarf mosaic virus from Columbia (M88179, M188180); BGMV-BR, bean golden mosaic virus from Brazil (M88687, M88687); BGMV-PR, BGMV from Puerto Rico (M10070, M10080); CaLCV, cabbage leaf curl virus from Florida (U65529); CLCrV, cotton leaf crumple virus from Arizona (Z. Xiong, personal communication); PepGMV, pepper golden mosaic virus from Mexico (U57457); PHV, pepper huasteco virus from Mexico (X70418, X70419); PYMV-VE, potato yellow mosaic virus from Venezuela (D00940, D00941); SiGMV-CR, Sida golden mosaic virus from Costa Rica (X99550, X99551); SiGMV-Flo, SiGMV from Florida (AF039841, AF0049336); SiGMV-HN, SiGMV from Honduras (Y11097, Y11098); SiGMV-HN/Yv, SiGMV yellow vein strain from Honduras (Y11099, Y11100); SLCV, squash leaf curl virus from California (M38182, M38183); TGMV, tomato golden mosaic virus (K020029, K02030); TLCrV, tomato leaf crumple virus from Mexico (L34747); ToLCV-PA, tomato leaf curl virus from Panama (Y15033, Y15034); ToMoV, tomato mottle virus from Florida (L14460, L14461); ToMoV-Tai, ToMoV Taino strain from Cuba (AF012300, AF012301); and ToLCV-Nde, tomato leaf curl virus from New Delhi, India (U15015, U15016).
(MP), respectively. They are likely to be essential for viral movement, based upon studies with other similar geminiviruses $(15,30)$.

Nucleotide sequences of DNA-A and DNA-B, the IR of DNA-A, and deduced amino acid sequences of the genes were compared with sequences of other geminiviruses to examine the relationship of the cloned virus to geminiviruses from the Americas (Table 3). When complete nucleotide sequences of the DNA-A and DNA-B were compared, the cloned virus had a higher percent identity with PYMV-VE and ToLCV-PA (85\% for DNA-A and 82\% for DNA-B) than to other viruses (Table 3). Among the individual proteins, TrAP, REn, MP, and NSP showed high degrees of identity with the respective proteins from PYMV from Trinidad and Tobago (PYMV-TT) and ToLCV-PA (84 to 99\%). The Rep protein, how

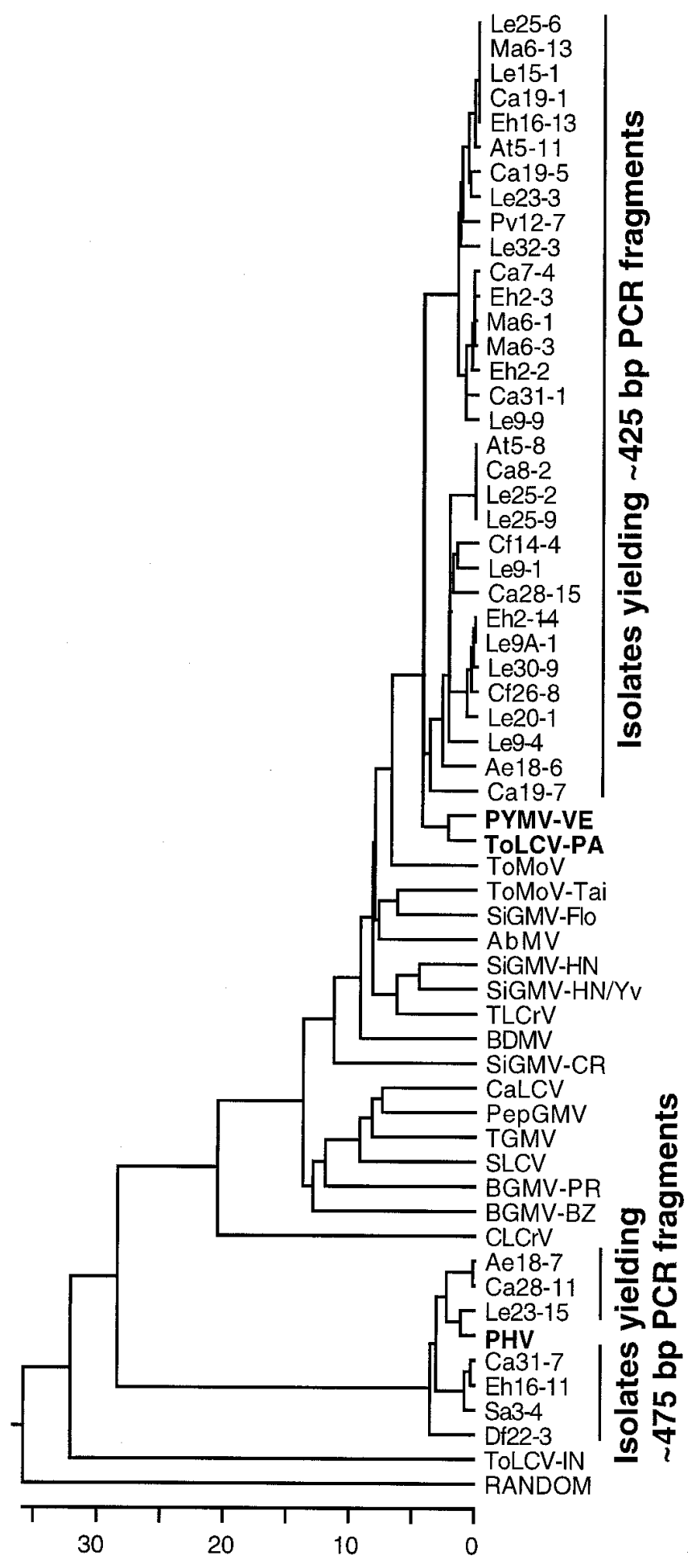

Vol. 88 , No. 12,1998 

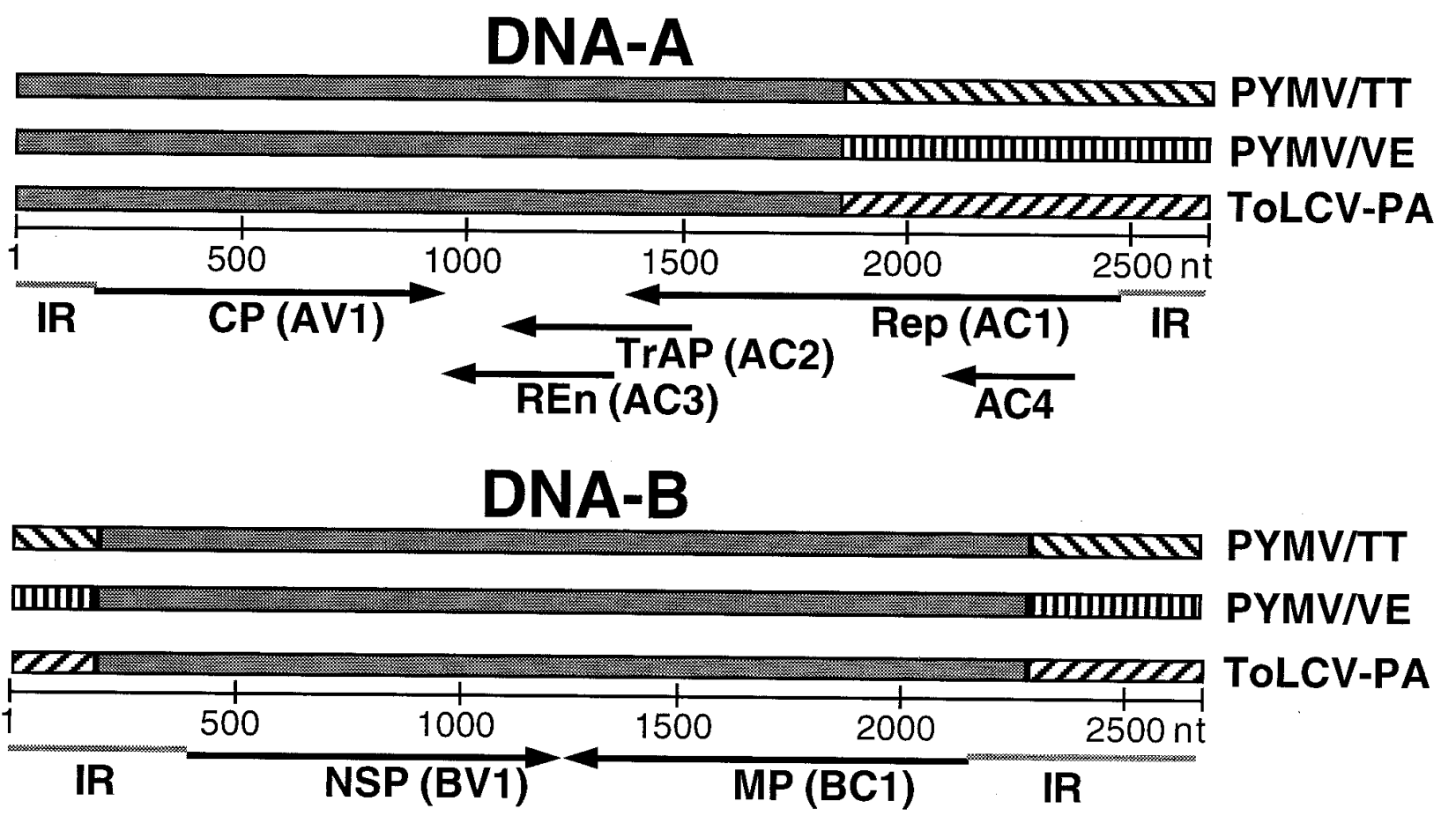

Fig. 2. Genome organization and recombination map of the tomato-infecting Trinidad and Tobago strain of potato yellow mosaic virus (PYMV-TT), potato yellow mosaic virus from Venezuela (PYMV-VE), and tomato leaf curl virus from Panama (ToLCV-PA). Genes that are conserved in other geminiviruses are shown as arrows. IR (intergenic region) represents an $\approx 320$-nucleotide sequence between the initiation codons of replication associated protein (Rep) and coat protein (CP) on DNA-A, and an $\approx 900$-nucleotide sequence between the initiation codons of nuclear shuttle protein (NSP) and movement protein (MP) on DNA-B. Shaded sections represent sequence similarity between the viruses and hatched regions denote sequence differences. Nucleotide A (TAATATTAC) in the invariable nonanucleotide, the nicking site for the Rep, is set as nucleotide \#1. GenBank accession numbers for DNA-A and DNA-B sequences of PYMV-TT are AF039031 and AF039032, respectively.

TABLE 3. Nucleotide and amino acid sequence identities (\%) between the tomato-infecting geminivirus from Trinidad and Tobago and other whitefly-transmitted geminiviruses ${ }^{\mathrm{a}}$

\begin{tabular}{|c|c|c|c|c|c|c|c|c|c|c|}
\hline Virus $^{\mathrm{b}}$ & A & B & IR & $\mathrm{CP}$ & Rep & TrAP & REn & $\mathrm{AC} 4$ & NSP & MP \\
\hline AbMV & 77 & 54 & 57 & 91 & 75 & 81 & 84 & 80 & 66 & 65 \\
\hline BGMV-BR & 72 & 51 & 45 & 90 & 76 & 70 & 77 & 44 & 64 & 72 \\
\hline $\mathrm{CaLCuV}$ & 66 & $\ldots$ & 39 & 89 & 61 & 66 & 75 & $\ldots$ & $\ldots$ & $\ldots$ \\
\hline CLCrV & 68 & $\ldots$ & 34 & 89 & 65 & 81 & 86 & $\ldots$ & $\ldots$ & $\ldots$ \\
\hline PepGMV & 63 & 51 & 33 & 89 & 59 & 63 & 75 & $\ldots$ & 66 & 80 \\
\hline PHV & 65 & 52 & 46 & 88 & 69 & 54 & 67 & 63 & 63 & 82 \\
\hline SiGMV-Flo & 75 & 58 & 53 & 93 & 83 & 83 & 84 & 76 & 69 & 90 \\
\hline SiGMV-HN & 81 & 58 & 63 & 92 & 86 & 79 & 77 & 77 & 73 & 90 \\
\hline SiGMV-HN/Yv & 78 & 57 & 57 & 93 & 82 & 82 & 77 & 76 & 72 & 89 \\
\hline SLCV & 65 & 46 & 45 & 91 & 59 & 63 & 74 & $\ldots$ & 56 & 80 \\
\hline TGMV & 71 & 50 & 34 & 88 & 78 & 69 & 81 & 64 & 63 & 87 \\
\hline ToLCV-PA & 85 & 81 & 74 & 98 & 82 & 89 & 92 & 63 & 84 & 96 \\
\hline ToMoV & 78 & 53 & 54 & 94 & 84 & 79 & 86 & 73 & 67 & 84 \\
\hline
\end{tabular}

${ }^{a} \mathrm{~A}$ and $\mathrm{B}$ are total nucleotide sequence of DNA-A and DNA-B, respectively. IR $=$ intergenic region, the $\approx 320$-bp nucleotide sequence between the initiation codons of the replication associated protein (Rep) and coat protein (CP) genes. CP through MP are amino acid sequences of genes that are conserved in whitefly-transmitted geminiviruses. TrAP $=$ transcriptional activator protein, $\mathrm{REn}=$ replication enhancer protein, $\mathrm{NSP}=$ nuclear shuttle protein, and $\mathrm{MP}=$ movement protein. $\ldots=$ Not present.

${ }^{\mathrm{b}}$ Geminivirus names and GenBank accession numbers: AbMV, Abutilon mosaic virus from West Indies (X15983, X15984); BDMV, bean dwarf mosaic virus from Columbia (M88179, M188180); BGMV-BR, bean golden mosaic virus from Brazil (M88687, M88687); BGMV-PR, BGMV from Puerto Rico (M10070, M10080); CaLCV, cabbage leaf curl virus from Florida (U65529); CLCrV, cotton leaf crumple virus from Arizona (Z. Xiong, personal communication); PepGMV, pepper golden mosaic virus from Mexico (U57457); PHV, pepper huasteco virus from Mexico (X70418, X70419); PYMV-VE, potato yellow mosaic virus from Venezuela (D00940, D00941); SiGMV-CR, Sida golden mosaic virus from Costa Rica (X99550, X99551); SiGMV-Flo, SiGMV from Florida (AF039841, AF0049336); SiGMV-HN, SiGMV from Honduras (Y11097, Y11098); SiGMV-HN/Yv, SiGMV yellow vein strain from Honduras (Y11099, Y11100); SLCV, squash leaf curl virus from California (M38182, M38183); TGMV-BR, tomato golden mosaic virus from Brazil (K020029, K02030); TLCrV, tomato leaf crumple virus from Mexico (L34747); ToLCV-PA, tomato leaf curl virus from Panama (Y15033, Y15034); ToMoV, tomato mottle virus from Florida (L14460, L14461); ToMoV-Tai, ToMoV Taino strain from Cuba (AF012300, AF012301); and ToLCV-Nde, tomato leaf curl virus from New Delhi, India (U15015, U15016). 
ever, was more similar to Sida golden mosaic virus from Honduras (SiGMV-HN, 86\%) and bean dwarf mosaic virus (BDMV, 85\%) than to other viruses, and the product of the AC4 gene (located within Rep gene but in a different reading frame) was similar to that of Abutilon mosaic virus (AbMV, 80\%) and SiGMV-HN (77\%). When the IR served as the basis for comparison, the cloned virus was closer to ToLCV-PA (74\%) than to other viruses (Table 3).

Recently, a strain of PYMV-VE was shown to infect tomato in Guadeloupe, Martinique, and Puerto Rico. PCR amplification and restriction digestion analysis of geminivirus-specific DNA from 34 samples suggested that they were infected by the same virus $(22,23)$. Nucleotide sequences of an infectious full-length DNA-A and DNA-B from Guadeloupe were 93 and $89 \%$ identical to sequences of DNA-A and DNA-B of PYMV-VE, respectively. Also recently, geminiviruses infecting tomato in Venezuela were characterized by sequencing partial clones of DNA-A obtained by PCR (12). Sequence comparisons (12) showed that tomato in Venezuela was infected by two geminiviruses; one virus was related to PYMVVE called tomato strain of PYMV-VE (PYMV-VE//To), and another appeared to be an undescribed geminivirus called Venezuelan tomato geminivirus (VToV). We compared partial sequences of the Rep gene (5' Rep, 720 nucleotides) and the CP gene (5' CP, $153 \mathrm{nu}-$ cleotides), the complete IR, the first half of the IR ( $5^{\prime}$ IR, from the initiation codon of the Rep gene to the end of the conserved stemloop, sometimes described as the common region) (9), and the second half of the IR ( $3^{\prime}$ IR, from the end of the conserved stem-loop to the initiation codon of the CP gene) of the cloned DNA-A with the corresponding regions of tomato-infecting geminiviruses from Venezuela and other geminiviruses (Table 4; only data from closely related viruses is shown). The partial Rep sequence of the tomatoinfecting geminivirus from Trinidad and Tobago is most closely related to SiGMV-HN and BDMV, and the partial CP sequence is closer to PYMV-VE and ToLCV-PA than to other viruses, as observed when complete Rep and CP gene products were compared. The first half of the IR is similar to the IR of SiGMV-HN, while the second half of the IR is more similar to PYMV-TT//To, VToV, PYMV-VE, and ToLCV-PA than to other viruses.

Several features stand out from these sequence comparisons and phylogenetic analyses (data not shown). First, the tomato-infecting geminivirus from Trinidad and Tobago appears to be a recombinant derived from PYMV-VE or ToLCV-PA and SiGMV-HN or some unknown virus (Fig. 2). It contains a part of DNA-A ( $3^{\prime}$ IR,

TABLE 4. Nucleotide sequence identity (\%) between the tomato-infecting geminivirus from Trinidad and Tobago and other closely related geminiviruses in the IR and 5' part of the Rep gene and the CP gene ${ }^{\mathrm{a}}$

\begin{tabular}{lccccc}
\hline Virus $^{\mathrm{b}}$ & $5^{\prime}$ Rep & 5' CP $^{\prime}$ & IR & $5^{\prime}$ IR & $3^{\prime}$ IR \\
\hline AbMV & 74 & 67 & 57 & 71 & 47 \\
BDMV & 80 & 83 & 51 & 62 & 44 \\
PYMV-VE & 76 & 94 & 61 & 46 & 81 \\
PYMV-VE//To & 72 & 86 & 65 & 50 & 83 \\
SiGMV-HN & 80 & 84 & 63 & 79 & 51 \\
ToLCV-PA & 71 & 94 & 74 & 69 & 79 \\
VToV & 77 & 90 & 74 & 64 & 83 \\
\hline
\end{tabular}

a $5^{\prime}$ replication associated protein (Rep) and $5^{\prime}$ coat protein $(\mathrm{CP})$ are the first 702 nucleotides of the Rep gene and the first 153 nucleotides of the $\mathrm{CP}$ gene, respectively. Intergenic region (IR) is the $\sim 320$-bp nucleotide sequence between the initiation codons of the Rep and CP genes. 5' IR and 3' IR are the first half of the IR (from the initiation codon of the Rep gene to the end of the conserved stem-loop, $\approx 150 \mathrm{bp}$ ) and the second half of the IR (from the end of the conserved stem-loop to the initiation codon of the CP gene, $\approx 160 \mathrm{bp}$ ), respectively. PYMV-VE//To = tomato strain of potato yellow mosaic virus from Venezuela (GenBank accession \#AF026553) and VtoV = Venezuela tomato geminivirus (GenBank accession \#AF026464).

b Other geminivirus names and GenBank accession numbers: AbMV, Abutilon mosaic virus from West Indies (X15983, X15984); BDMV, bean dwarf mosaic virus from Columbia (M88179, M188180); PYMV-VE, potato yellow mosaic virus from Venezuela (D00940, D00941); SiGMV-HN, Sida golden mosaic virus from Honduras (Y11097, Y11098); and ToLCV-PA, tomato leaf curl virus from Panama (Y15033, Y15034).
CP, TrAP, and REn) that is very similar to PYMV-VE and ToLCVPA and another part (Rep and $5^{\prime}$ IR) that is similar to SiGMV-HN. Second, the 3' IR and CP of PYMV-VE and the tomato-infecting geminiviruses from Trinidad and Tobago, Venezuela, and Panama are more similar to each other than to other viruses. But these viruses differ from each other and from other viruses in Rep and $5^{\prime}$ IR sequence. Third, the tomato-infecting geminivirus from Trinidad and Tobago can be considered to be a strain of PYMV, and we propose that it should be called potato yellow mosaic virus from Trinidad and Tobago (PYMV-TT). Similarly, ToLCV-PA may be called PYMV-PA. Fourth, the widespread distribution of strains or isolates related to PYMV appears to be responsible for the epidemics in tomato in Trinidad and Tobago, Venezuela, Guadeloupe, Martinique, and Puerto Rico.

PYMV was first isolated from an infected potato sample from Venezuela (5) and is the only geminivirus known to naturally infect potato $(25,26)$. PYMV and its related and other geminiviruses can be distinguished by PCR amplification and sequencing. PCR has been used to detect geminiviruses previously $(8,21,27,28)$. The analysis can be made easier provided a correspondence between amplified fragment size and specific geminiviruses can be established as was done in this study. Such a study provides a snapshot of the geminivirus situation and can be pursued on a recurrent basis to monitor the spread of geminiviruses.

Vegetable production in Trinidad and Tobago is carried out in small holdings dispersed in predominantly agricultural localities, where a number of crops are grown simultaneously by independent farmers. This study shows that the WTGs have a wide host range and can infect a number of crop plants such as tomato, pepper, okra, and beans during the crop season and can survive in a number of weed species during the noncrop season. If the ubiquitous nature of whiteflies, which often occur in epidemic proportions, are superimposed on this scenario, it is not difficult to comprehend the WTG epiphytotics observed in tomato crops. A possible strategy to reduce the problem in the short run may be to institute a crop-free period in each agricultural locality and to advocate a rigid coordinated program of whitefly management during the crop season. In the long run, efforts should be made to introduce varieties resistant to these viruses. The isolation and sequencing of PYMV from Trinidad and Tobago represents the first step toward developing strategies to control the disease (10).

\section{ACKNOWLEDGMENTS}

P. Umaharan received a fellowship from the University of the West Indies under the UWI/IDB staff development project. We thank J. E. Polston for supplying tomato mottle virus clones and V. Gajadharsingh for technical assistance.

\section{LITERATURE CITED}

1. Abouzid, A. M., Polston, J. E., and Hiebert, E. 1992. The nucleotide sequence of tomato mottle virus, a new geminivirus isolated from tomatoes in Florida. J. Gen. Virol. 73:3225-3229.

2. Brown, J. K., and Bird, J. 1992. Whitefly-transmitted geminiviruses and associated disorders in the Americas and the Caribbean basin. Plant Dis. 76:220-225.

3. Brown, J. K., and Nelson, M. R. 1988. Transmission, host range, and virus-vector relationships of chino del tomate virus, a whitefly-transmitted geminivirus from Sinaloa, Mexico. Plant Dis. 72:866-869.

4. Buragohain, A. K., Sung, Y. K., Coffin, R. S., and Coutts, R. H. A. 1994. The infectivity of dimeric potato yellow mosaic geminivirus in different hosts. J. Gen. Virol. 75:2857-2861.

5. Coutts, R. H. A., Coffin, R. S., Roberts, E. J. F., and Hamilton, W. D. O. 1991. The nucleotide sequence of the infectious cloned DNA components of potato yellow mosaic virus. J. Gen. Virol. 72:1515-1520.

6. Davies, J. W., and Stanley, J. 1989. Geminivirus genes and vectors. Trends Genet. 5:77-81.

7. Dellaporta, S. L., Wood, J., and Hicks, J. B. 1983. A plant DNA minipreparation: Version II. Plant Mol. Biol. Rep. 1:19-21.

8. Deng, D., McGrath, P. F., Robinson, D. J., and Harrison, B. D. 1994. 
Detection and differentiation of whitefly-transmitted geminiviruses in plants and vector insects by the polymerase chain reaction with degenerate primers. Ann. Appl. Biol. 125:327-336.

9. Faria, J. C., Gilbertson, R. L., Hanson, S. F., Morales, F. J., Ahlquist, P., Loniello, A. O., and Maxwell, D. P. 1994. Bean golden mosaic geminivirus type II isolates from the Dominican Republic and Guatemala: Nucleotide sequences, infectious pseudorecombinants, and phylogenetic relationships. Phytopathology 84:321-329.

10. Frischmuth, T., and Stanley, J. 1995. Strategies for the control of geminivirus disease. Semin. Virol. 4:329-337.

11. Garzon-Tiznado, J. A., Torres-Pacheco, I., Ascencio-Ibanez, J. T., HerreraEstrella, L., and Rivera-Bustamante, R. F. 1993. Inoculation of peppers with infectious clones of a new geminivirus by a biolistic procedure. Phytopathology 83:514-521.

12. Guzman, P., Arredondo, C. R., Emmatty, D., Portillo, R. J., and Gilbertson, R. L. 1997. Partial characterization of two whiteflytransmitted geminiviruses infecting tomatoes in Venezuela. Plant Dis. $81: 312$.

13. Harrison, B. D. 1985. Advances in geminivirus research. Annu. Rev. Phytopathol. 23:55-82.

14. Hong, Y. G., and Harrison, B. D. 1995. Nucleotide sequences from tomato leaf curl viruses from different countries: Evidence for three geographically separate branches in evolution of the coat protein of whitefly-transmitted geminiviruses. J. Gen. Virol. 76:2043-2049.

15. Ingham, D. J., Pascal, E., and Lazarowitz, S. G. 1995. Both bipartite geminivirus movement proteins define viral host range, but only BL1 determines viral pathogenicity. Virology 207:191-204.

16. Lazarowitz, S. G. 1992. Geminiviruses: Genome structure and gene function. Crit. Rev. Plant Sci. 11:327-349.

17. Lazarowitz, S. G., and Lazdin, I. B. 1991. Infectivity and complete nucleotide sequence of the cloned genomic components of a bipartite squash leaf curl geminivirus with a broad host range phenotype. Virology 180:58-69.

18. Mayo, M. A., and Martelli, G. P. 1993. New families and genera of plant viruses. Arch. Virol. 133:496-498.

19. Padidam, M., Beachy, R. N., and Fauquet, C. M. 1995. Tomato leaf curl geminivirus from India has a bipartite genome and coat protein is not essential for infectivity. J. Gen. Virol. 76:25-35.

20. Padidam, M., Beachy, R. N., and Fauquet, C. M. 1995. Classification and identification of geminiviruses using sequence comparisons. J. Gen.
Virol. 76:249-263.

21. Paplomatas, E. J., Patel, V. P., Hou, Y.-M., Noueiry, A. O., and Gilbertson, R. L. 1994. Molecular characterization of a new sap-transmissible bipartite genome geminivirus infecting tomatoes in Mexico. Phytopathology 84: 1215-1224.

22. Polston, J. E., and Anderson, P. K. 1997. The emergence of whiteflytransmitted geminiviruses in tomato in the western hemisphere. Plant Dis. 81:1358-1369.

23. Polston, J. E., Bois, D., Ano, G., Poliakoff, F., and Urbino, C. 1998. Occurrence of a strain of potato yellow mosaic geminivirus infecting tomato in the eastern Caribbean. Plant Dis. 82:126.

24. Polston, J. E., Hiebert, E., McGovern, R. J., Stansly, P. A., and Schuster, D. J. 1993. Host range of tomato mottle virus, a new geminivirus infecting tomato in Florida. Plant Dis. 77:1181-1184.

25. Roberts, E. J. F., Buck, K. W., and Coutts, R. H. A. 1986. A new geminivirus infecting potato in Venezuela. Plant Dis. 70:603.

26. Roberts, E. J. F., Buck, K. W., and Coutts, R. H. A. 1988. Characterization of potato yellow mosaic virus as a geminivirus with a bipartite genome. Intervirology 29:162-169.

27. Rojas, M. R., Gilbertson, R. L., Russell, D. R., and Maxwell, D. P. 1993. Use of degenerate primers in the polymerase chain reaction to detect whitefly-transmitted geminiviruses. Plant Dis. 77:340-347.

28. Rybicki, E. P., and Hughes, F. L. 1990. Detection and typing of maize streak virus and other distantly related geminiviruses of grasses by polymerase chain reaction amplification of a conserved viral sequence. $\mathrm{J}$. Gen. Virol. 71:2519-2526.

29. Sambrook, J., Fritsch, E. F., and Maniatis, T. 1989. Molecular Cloning: A Laboratory Manual, 2nd ed. Cold Spring Harbor Laboratory Press, Cold Spring Harbor, NY.

30. Sunter, G., Gardiner, W. E., Rushing, A. E., Rogers, S. G., and Bisaro, D. M. 1987. Independent encapsidation of tomato golden mosaic virus A component DNA in transgenic plants. Plant Mol. Biol. 8:477-484.

31. Timmermans, M. C. P., Das, O. P., and Messing, J. 1994. Geminiviruses and their uses as extrachromosomal replicons. Annu. Rev. Plant Physiol. Plant Mol. Biol. 45:79-112.

32. Torres-Pacheco, I., Garzon-Tiznado, J. A., Herrera-Estrella, L., and RiveraBustamante, R. F. 1993. Complete nucleotide sequence of pepper huasteco virus: Analysis and comparison with bipartite geminiviruses. J. Gen. Virol. $74: 2225-2231$ 